\title{
Tahapan dalam Menentukan Proses Keperawatan
}

\author{
Yosepine Megawati \\ yosepinemegawati28@gmail.com
}

\section{LATAR BELAKANG}

Keperawatan merupakan suatu unit pelayanan kesehatan masyarakat yang bertugas untuk memenuhi kebutuhan sehat maupun sakit pada masyarakat. Keperawatan juga merupakan unit pelayanan profesional berdasarkan ilmu keperawatan yang berbentuk fisik dan biologis. Keperawatan juga memiliki peranan yang sangat penting dalam keberhasilan keselamatan dan kesehatan pasien. Perawat juga mempunyai peran penting dalam kualitas di rumah sakit yaitu dengan menjaga bio-psiko-sosio dan spiritual pasien. Perawat juga bertugas untuk memberikan asuhan keperawatan kepada pasien dan keluarga. Asuhan keperawatan yang diberikan seorang perawat kepada pasien dan keluarga harus berdasarkan ilmu yang telah dipelajari oleh seorang perawat. Asuhan keperawatan menjadi tolak ukur dalam menjalankan proses keperawatan yaitu agar seorang perawat tidak lepas dari tanggung jawab dan tetap menjaga etika terhadap pasien dan keluarga.

Perawat dalam memberikan asuhan keperawatan kepada klien, membutuhkan suatu proses, proses tersebut yaitu proses keperawatan. Proses keperawatan merupakan suatu pendekatan yang bertujuan untuk memecahkan masalah yang mendukung kemampuan perawat untuk mengatur dan memberikan asuhan keperawatan. Dalam proses keperawatan terdapat tahap-tahapan yang dilakukan, lalu tahapan tersebut memiliki sifat yang dimana akan mempengaruhi hasil dari proses keperawatan

Proses keperawatan dapat terlaksana dengan baik apabila pendokumentasiannya akurat. Proses keperawatan sangat barkaitan dengan asuhan keperawatan. Agar asuhan keperawatan dapat terlaksana dengan seksama dibutuhkan tahapan - tahapan proses keperawatan sehingga asuhan keperawatan dapat tersusun secara sistematis dan terencana. Asuhan keperawatan sangat berpengaruh kepada kualitas pelayanan kesehatan. Seorang perawat memiliki pedoman dalam melaksanakan asuhan keperawatan yaitu standar praktik keperawatan. Oleh karena itu proses keperawatan sangat berpengaruh dalam asuhan keperawatan. Proses keperawatan merupakan metode ilmiah yang digunakan dalam memberikan asuhan keperawatan yang 
profesional. Perawat diharapkan dapat mengevaluasi dan menyetujui konsep proses keperawatan yang terdiri dari Pengkajian, Diagnosa Keperawatan, Implementasi, Evaluasi.

\section{METODE}

Metode yang digunakan adalah metode kualitatif. Metode kualitatif adalah metode riset yang sifatnya memberikan penjelasan dengan menggunakan analisis. Menurut Sugiyono (2011), metode penelitian kualitatif adalah metode penelitian yang berlandaskan pada filsafat post positivisme, digunakan untuk meneliti pada kondisi obyek yang alamiah, (sebagai lawannya eksperimen) dimana peneliti adalah sebagai instrumen kunci, pengambilan sampel sumber data dilakukan secara purposive dan snowball, teknik pengumpulan dengan tri-anggulasi (gabungan), analisis data bersifat induktif atau kualitatif, dan hasil penelitian kualitatif lebih menekankan makna dari pada generalisasi.

\section{HASIL}

Proses keperawatan merupakan suatu pendekatan yang bertujuan untuk memecahkan masalah yang mendukung kemampuan perawat untuk mengatur dan memberikan asuhan keperawatan. Dalam proses keperawatan terdapat tahap-tahapan yang dilakukan, lalu tahapan tersebut memiliki sifat yang dimana akan mempengaruhi hasil dari proses keperawatan.

Tahap - Tahap Proses Keperawatan

\section{Pengkajian}

Tahap ini mencakup tiga kegiatan,yaitu Pengumpulan Data, Analisis Data dan Penentuan Masalah kesehatan serta keperawatan.

2. Diagnosa Keperawatan

Diagnosa Keperawatan adalah suatu pernyataan yang menjelaskan respon manusia (status kesehatan atau resiko perubahan pola) dari individu atau kelompok dimana perawat secara akuntabilitas dapat mengidentifikasi dan memberikan intervensi secara pasti untuk menjaga status kesehatan menurunkan, membatasi, mencegah dan merubah.

3. Rencana keperawatan

Rencana asuhan keperawatan tertulis mengatur pertukaran informasi oleh perawat dalam laporan pertukaran dinas. Rencana perawatan tertulis juga mencakup kebutuhan klien jangka panjang

4. Implementasi keperawatan 
Adapun tahap-tahap dalam tindakan keperawatan adalah sebagai berikut :

Tahap 1 : persiapan

Tahap 2 : intervensi

Tahap 3 : dokumentasi

5. Evaluasi

Perencanaan evaluasi memuat kriteria keberhasilan proses dan keberhasilan tindakan keperawatan. Keberhasilan proses dapat dilihat dengan jalan membandingkan antara proses dengan pedoman/rencana proses tersebut.

Setelah seorang perawat melakukan seluruh proses keperawatan dari pengkajian sampai dengan evaluasi kepada pasien ,seluruh tindakannya harus didokumentasikan dengan benar dalam dokumentasi keperawatan. Setiap tahap ini harus terlaksana secara berurutan dan tidak boleh ada yang hilang, karena tahap - tahap proses keperawatan ini saling berkaitan dan tidak dapat dipisahkan.

\section{PEMBAHASAN}

Proses keperawatan adalah serangkaian tindakan yang sistematis berkesinambungan meliputi tindakan untuk mengidentifikasi masalah kesehatan individu atau kelompok baik yang actual maupun potensial kemudian merencanakan tindakan untuk menyelesaikan, mengurangi, atau mencegah terjadinya masalah baru dan melaksanakan tindakan atau menugaskan orang lain untuk melaksanakan tindakan keperawatan serta mengevaluasi keberhasilan dari tindakan yang dikerjakan. Keperawatan dalam menjalankan tugasnya menggunakan metode proses keperawatan. Proses keperawatan merupakan suatu kegiatan untuk memenuhi kebutuhan pasien dalam mencapai dan memlihara kesehatannya seoptimal mungkin, yang dilaksanakan secara terstruktur dan berurutan. Proses keperawatan ini memiliki fungsi

memberikan asuhan keperawatan kepada pasien secara ilmiah agar fungsi dan tanggung jawab keperawatan terlaksana dengan baik.

Tahap - Tahap Proses Keperawatan

1. Pengkajian

Pengkajian adalah upaya mengumpulkan data secara lengkap dan sistematis untuk dikaji dan dianalisis sehingga masalah kesehatan dan keperawatan yang di hadapi pasien baik fisik, mental, 
sosial maupun spiritual dapat ditentukan.tahap ini mencakup tiga kegiatan,yaitu Pengumpulan Data, Analisis Data dan Penentuan Masalah kesehatan serta keperawatan.

a. Pengumpulan data

Tujuan: Diperoleh data dan informasi mengenai masalah kesehatan yang ada pada pasien sehingga dapat ditentukan tindakan yang harus diambil untuk mengatasi masalah tersebut yang menyangkut aspek fisik, mental, sosial dan spiritual serta faktor lingkungan yang mempengaruhinya. Data tersebut harus akurat dan mudah dianalisis.

Jenis data antara lain:

- Data Objektif, yaitu data yang diperoleh melalui suatu pengukuran, pemeriksaan, dan pengamatan, misalnya suhu tubuh, tekanan darah, serta warna kulit.

- Data subjekif, yaitu data yang diperoleh dari keluhan yang dirasakan pasien, atau dari keluarga pasien/saksi lain misalnya; kepala pusing, nyeri dan mual.

Adapun focus dalam pengumpulan data meliputi :

- Status kesehatan sebelumnya dan sekarang

- Pola koping sebelumnya dan sekarang

- Fungsi status sebelumnya dan sekarang

- Respon terhadap terapi medis dan tindakan keperawatan

- Resiko untuk masalah potensial

- Hal-hal yang menjadi dorongan atau kekuatan klien

b. Analisa data

Analisa data adalah kemampuan dalam mengembangkan kemampuan berpikir rasional sesuai dengan latar belakang ilmu pengetahuan.

c. Perumusan masalah

Setelah analisa data dilakukan, dapat dirumuskan beberapa masalah kesehatan. Masalah kesehatan tersebut ada yang dapat diintervensi dengan Asuhan Keperawatan (Masalah Keperawatan) tetapi ada juga yang tidak dan lebih memerlukan tindakan medis. Selanjutnya disusun Diagnosis Keperawatan sesuai dengan prioritas. Prioritas masalah ditentukan berdasarkan kriteria penting dan segera. Penting mencakup kegawatan dan apabila tidak diatasi akan menimbulkan komplikasi, sedangkan Segera mencakup waktu misalnya pada pasien stroke yang tidak sadar maka tindakan harus segera dilakukan untuk mencegah komplikasi yang lebih parah atau kematian. Prioritas masalah juga dapat 
ditentukan berdasarkan hierarki kebutuhan menurut Maslow, yaitu : Keadaan yang mengancam kehidupan, keadaan yang mengancam kesehatan, persepsi tentang kesehatan dan keperawatan

\section{Diagnosa Keperawatan}

Diagnosa Keperawatan adalah suatu pernyataan yang menjelaskan respon manusia (status kesehatan atau resiko perubahan pola) dari individu atau kelompok dimana perawat secara akuntabilitas dapat mengidentifikasi dan memberikan intervensi secara pasti untuk menjaga status kesehatan menurunkan, membatasi, mencegah dan merubah.

\section{Rencana keperawatan}

Semua tindakan yang dilakukan oleh perawat untuk membantu klien beralih dari status kesehatan saat ini kestatus kesehatan yang di uraikan dalam hasil yang di harapkan. Merupakan pedoman tertulis untuk perawatan klien. Rencana perawatan terorganisasi sehingga setiap perawat dapat dengan cepat mengidentifikasi tindakan perawatan yang diberikan. Rencana asuhan keperawatan yang di rumuskan dengan tepat memfasilitasi konyinuitas asuhan perawatan dari satu perawat ke perawat lainnya. Sebagai hasil, semua perawat mempunyai kesempatan untuk memberikan asuhan yang berkualitas tinggi dan konsisten.

Rencana asuhan keperawatan tertulis mengatur pertukaran informasi oleh perawat dalam laporan pertukaran dinas. Rencana perawatan tertulis juga mencakup kebutuhan klien jangka panjang

4. Implementasi keperawatan

Merupakan inisiatif dari rencana tindakan untuk mencapai tujuan yang spesifik. Tahap pelaksanaan dimulai dimulai setelah rencana tindakan disusun dan ditujukan pada nursing orders untuk membantu klien mencapai tujuan yang diharapkan. Oleh karena itu rencana tindakan yang spesifik dilaksanakan untuk memodifikasi faktor-faktor yang mempengaruhi masalah kesehatan klien.

Adapun tahap-tahap dalam tindakan keperawatan adalah sebagai berikut :

Tahap 1 : persiapan

Tahap 2 : intervensi

Tahap 3 : dokumentasi

5. Evaluasi 
Perencanaan evaluasi memuat kriteria keberhasilan proses dan keberhasilan tindakan keperawatan. Keberhasilan proses dapat dilihat dengan jalan membandingkan antara proses dengan pedoman/rencana proses tersebut. Sedangkan keberhasilan tindakan dapat dilihat dengan membandingkan antara tingkat kemandirian pasien dalam kehidupan sehari-hari dan tingkat kemajuan kesehatan pasien dengan tujuan yang telah di rumuskan sebelumnya.

Setelah seorang perawat melakukan seluruh proses keperawatan dari pengkajian sampai dengan evaluasi kepada pasien ,seluruh tindakannya harus didokumentasikan dengan benar dalam dokumentasi keperawatan.

Proses keperawatan memiliki beberapa tahap mulai dari pengkajian, perencanaan, pelaksana tindakan/implementasi dan evaluasi. Setiap tahap ini harus terlaksana secara berurutan dan tidak boleh ada yang hilang, karena tahap - tahap proses keperawatan ini saling berkaitan dan tidak dapat dipisahkan. Jika salah satu dari tahap proses keperawatan ini tidak dilakukan maka proses keperawatan tidak akan terlaksana dengan baik. Proses keperawatan harus diterapkan dalam asuhan keperawatan untuk melaksanakan tanggung jawab dan tanggung gugat perawat terhadap pasien. Asuhan keperawatan sendiri merupakan rangkaian kegiatan seorang perawat terhadap pasien dalam memberikan pelayanan kesehatan. Asuhan keperawatan harus ditingkatkan agar pendokumentasian pasien dapat terlaksana berdasarkan proses keperawatan. Seorang perawat harus memberikan asuhan keperawatan yang tepat kepada pasien agar proses keperawatan yang diberikan tidak salah tindakan.

\section{PENUTUP}

Dalam Asuhan Keperawatan kita perlu memahami dan menerapkan standar proses keperawatan baik di Rumah Sakit maupun di Puskesmas namun dari hasil observasi terhadap jurnal yang membahas tentang penerapan standar proses keperawatan didapatkan standar proses keperawatan masih tidak baik, maka dari itu kita sebagai perawat atau mahasiswa perawat harus menerapkan dan meningkatkan proses ini dalam kinerja kita sebagai perawat.

Proses keperawatan mendukung tingkat penyelesaian masalah yang mendukung kesembuhan klien dan peningkatan mutu kesehatan yang akan datang. Proses keperawatan yang benar memberi manfaat dalam pelaksanaan tindakan asuhan keperawatan yang menjamin mutu peningkatan derajat kesehatan yang baik 


\section{DAFTAR PUSTAKA}

Budiono. (2016). Konsep Dasar Keperawatan. Jakarta: Pusdik SDM Kesehatan

Dermawan, D. (2012). Proses Keperawatan: Penerapan Konsep \& Kerangka Kerja. Yogyakarta: Gosyen

Hermawan, I. (2019). Metodologi Penelitian Pendidikan Kuantitatif, Kualitatif, dan Mixed Methode. Kuningan: Hidayatul Quran

Mugianti, S. (2016). Manajemen dan Kepemimpinan dalam Praktek Keperawatan. Jakarta: Pusdik SDM Kesehatan

Rosdahl, Caroline Bunker. (2014). Buku Ajar Keperawatan Dasar. Jakarta: EGC

Setiadi. (2012). Konsep \& Penulisan Dokumentasi Asuhan Keperawatan; Teori dan Praktik. Yogyakarta : Graha Ilmu

Simamora, R. H. (2019). Development of Guidelines for Applying appropriate Patient Identification to Achieve Patient Safety Goal INC2019 12th International Nursing Conference. 2019.10455 - 455 (1 pages) UCI(KEPA) : I410-ECN-0101-2019-512001224337

Simamora. R. H. (2008) The correlation of ward chief's giving direction and command and the performance of on-duty nurses at Jember dr. Subandi general hospital inpatient wards. jurnal Administrasi dan Kebijakan Kesehatan, (https://fkm.unair.ac.id/jurnal-administr)

Sudarta, W (2015). Managemen Keperawatan. Yogyakarta: GosyenPublishing

Susionto, R. (2015). Penerapan Standar Proses Keperawatan. Jurnal Keperawatan Soedirman. $5,82-83$

Vaughans, Bennita W. (2013). Keperawatan Dasar - Ed 1.Yogyakarta: Rapha Publishing.

Wahyuni E., Candaa P. (2019). Fakta yang Berhubungan dengan Mutu Pendokumentastian Asuhan Keperawatan. Fundamental And Management Nursing Journal, 2, 16-23. 